\title{
Severe Acute Pancreatitis - How Conservative Can We Be?
}

\author{
Christian Alberts Guido Alsfasser \\ Department of General, Thoracic, Vascular and Transplantation Surgery, University of Rostock, Rostock, Germany
}

\section{Keywords}

Acute pancreatitis - Infected pancreatic necrosis . Conservative treatment

\section{Summary}

Background: Acute pancreatitis still is a disease with overall high mortality. Continuously improved understanding of the pathophysiology, however, led to changes in treatment algorithms within the last decades, thus resulting in decreased mortality. This knowledge of acute pancreatitis enabled a new classification system introduced by an international expert panel. This classification system is helpful in initiating treatment strategies which are adapted to the course of acute pancreatitis. Especially the role of surgery experienced a paradigm shift towards a more conservative approach. Methods: A specific literature search regarding the treatment of acute pancreatitis was performed in the PubMed database, and the results of key studies were compared. Results of these studies are discussed in the context of the most recent international classification system. Results and Conclusion: Based upon the available data, we can summarize that conservative treatment of acute pancreatitis with pancreatic necrosis is a valid treatment option for selected cases and is associated with reduced mortality compared to more aggressive therapy. However, patients with acute pancreatitis should be treated in experienced centers.

(c) 2018 S. Karger GmbH, Freiburg

Data from this manuscript have in part been presented at the symposium 'Frontiers in Surgical Evolution' on September 21, 2018 in honor of Prof. Dr. Ernst Klar, Rostock, Germany.

\section{Introduction}

Acute pancreatitis is a potential life-threatening disease, and our understanding of its pathology and pathophysiology has been constantly growing during the last decades. The first internationally used classification system did not include all important aspects and soon the need for a revision became obvious [1]. In 2012, the Acute Pancreatitis Classification Working Group published an updated classification system which is based upon the current understanding of the pathophysiology of acute pancreatitis [2]. Acute pancreatitis is only considered severe if persistent organ failure is present. Severe pancreatitis is often accompanied by local necrosis, i.e. either pancreatic or peripancreatic necrosis. A very important point, however, is the distinction between the different phases of the disease. The early phase of acute pancreatitis is characterized by the systemic response to the local inflammation. This response leads to an activation of multiple cytokine cascades [3-5].

\section{Therapeutic Strategies in Acute Pancreatitis}

Based upon this pathophysiologic understanding, it is obvious that intensive care treatment is the only meaningful therapeutic option in the early course of the disease. Surgical therapy can only target local complications like necrosis, ischemia, or perforations. Necrotizing pancreatitis is a local complication of acute pancreatitis, which develops in up to $20 \%$ of patients and is associated with high mortality rates [6]. The medical and surgical management of necrotizing pancreatitis has been the subject of debate over the past decades. Traditionally, extensive resection played an important role in approaching severe acute pancreatitis [7-10]. In the 1980s, based upon new technological advances such as the improvement of different diagnostic tools, a new surgical approach was developed which targeted debridement of necrotic tissue rather than ex-

\section{KARGER}

() 2018 S. Karger GmbH, Freiburg

Fax +497614520714
Guido Alsfasser, MD, FACS

Department of General, Thoracic, Vascular and Transplantation Surgery University of Rostock

Schillingallee 35, 18057 Rostock, Germany

guido.alsfasser@med.uni-rostock.de 
tensive resection [11]. Removal of necrotic tissue became mandatory in the management of necrotizing pancreatitis, and early open intervention has been broadly adopted regardless of sterile or infected necrosis [12]. The primary target was the complete removal of the necrotic tissue, which often resulted in many reoperations. In the early 1990s, the therapeutic approach to sterile necrosis in acute pancreatitis became more conservative and the early management of severe acute necrotizing pancreatitis was shifted to the intensive care without any surgical intervention $[13,14]$.

In the 2000s, the conservative approach is broadly adopted when dealing with sterile necrosis and can be prioritized for stable general conditions, even if a diagnosis of infectious necrotizing pancreatitis has been made [15-17]. The presence of infection can be established with a positive fine needle aspiration (FNA) [18]. The contemporary approach to patients with necrotizing pancreatitis with or without infected necrosis is intensive care and delaying of an intervention as late as possible [19]. Available methods for intervention include percutaneous drainage as well as endoscopic, retroperitoneoscopic, laparoscopic, and open approaches [20-23].

Evidence-based guidelines have been established that provide recommendations concerning the medical and surgical management of acute pancreatitis with necrosis. Only in rare cases of ongoing gastric outlet, intestinal or biliary obstruction due to mass effect of walled-off necrosis, persistent pain, or disconnected duct syndrome, an intervention in sterile necrosis is indicated [24]. According to some authors, intervention in necrotizing pancreatitis is only indicated when infection is suspected and a clinical deterioration occurs - mostly due to ongoing organ failure for several weeks $[6,13]$. However, regardless of the timing, emergency surgery is indicated in cases of abdominal compartment syndrome and intestinal perforation as a result of fulminant necrotic pancreatitis [14].

\section{Timing of Intervention}

In the past decades, many study groups discussed the optimal timing for a surgical intervention, leading to different results. There were groups, mostly surgeons, advocating debridement of sterile pancreatic necrosis in the early phase. Others favored later interventions when signs of infected necrosis appeared $[7,9,10,12$, 13]. The advantages of delayed intervention soon became clear. Those advantages included the presence of walled-off necrosis with easier debridement at a later time, clearer computed tomography depictions of the extent of the infectious process, and better control of the metabolic and organ consequences of necrotizing pancreatitis [25]. The only prospective randomized study that investigated the timing of intervention consisted of two groups of patients with severe necrotizing pancreatitis [26]. One group included early necrosectomy within $72 \mathrm{~h}$ and the other delayed necrosectomy until day 12. The study was stopped prior to its scheduled conclusion date due to an excessive mortality rate in early intervention patients. This study clearly demonstrated an advantage of a delayed approach [26]. Since the 1990s, an advantage of delayed intervention over early intervention could be shown in different groups
[26-32]. In those studies, the time considered best for an intervention ranged from 2-6 weeks. Contemporary guidelines recommend performing necrosectomy no sooner than 4 weeks after onset of acute pancreatitis. At this time, necrosis has been sufficiently walled off $[6,17,19,33,34]$.

\section{How Conservative Can We Be?}

Conservative treatment is considered the international standard in acute pancreatitis with sterile necrosis $[19,35]$. However, there are numerous studies evaluating conservative treatment of infected necrosis [16, 36-38]. A systematic review of 12 studies analyzed a total of 409 patients with infected pancreatic necrosis [16]. This review demonstrated that conservative management in patients with infected necrosis without necrosectomy was a successful approach in $64 \%$ of patients. Another analysis of 639 consecutive patients with necrotizing pancreatitis showed that $62 \%$ of patients can be treated without intervention and with low mortality [17]. Other authors confirmed the safety and feasibility of conservative treatment of infected pancreatic necrosis as well [36-38]. Looking at all the special considerations in these different studies, it is very important to point out that patients with acute necrotizing pancreatitis should be treated in specialized centers only $[19,35]$.

In 2012, our group demonstrated a significantly reduced mortality if patients were treated more conservatively [39]. All patients had a severe course of the disease and showed unfavorable prognostic scores upon admission. Patients of group 1 were operated if routine FNA was positive and subsequent open necrosectomy was performed. Patients of group 2 were treated conservatively for at least 3 weeks. Most patients of group 2 received interventional drainage or, in rare cases, operation. The only indications for these operations were perforation, ischemia, or other emergency situations, whereas planned necrosectomy was not included. Mortality in group 2 was significantly lower with $8.3 \%$ versus $45 \%$ in group 1 . $38 \%$ of group 2 did not receive any intervention or operation at all. Interestingly, in regard to demographic or prognostic data, these patients were comparable to the $62 \%$ which needed an intervention or operation. We could not determine the percentage of infected necrosis in group 2. However, based upon the extent of necrosis in all these patients, it was very likely that a high percentage of infected necrosis was present. In a long-term follow-up of this group of patients, we could see that the long-term survival of conservatively treated patients with severe acute pancreatitis was significantly better even after $>20$ years compared to those patients who received open necrosectomy.

\section{Conclusion}

Based upon the presented data, we deem pure conservative treatment without any intervention or operation a safe treatment option which does not negatively affect long-term survival. There is no immediate need for any intervention in the early phase of the 
disease as long as the patient remains stable, even in the case of stable multi-organ dysfunction. Only rapid deterioration could call for an operation. This concept applies to sterile and infected necrosis. However, considerable experience in the treatment of acute pancreatitis is mandatory and these patients need to be transferred to experienced centers.

\section{Disclosure Statement}

The authors have no ethical conflicts to disclose. The authors have no conflicts of interest to declare. There was no funding provided for this review. Both authors contributed to the literature search and writing of the manuscript.

\section{References}

1 Bradley EL 3rd: A clinically based classification system for acute pancreatitis. Summary of the International Symposium on Acute Pancreatitis, Atlanta, GA, September 11 through 13, 1992. Arch Surg 1993;128:586590.

2 Banks PA, Bollen TL, Dervenis C, Gooszen HG, Johnson CD, Sarr MG, Tsiotos GG, Vege SS: Classification of acute pancreatitis - 2012: revision of the Atlanta classification and definitions by international consensus. Gut 2013;62:102-111.

3 Buter A, Imrie CW, Carter CR, Evans S, McKay CJ: Dynamic nature of early organ dysfunction determines outcome in acute pancreatitis. Br J Surg 2002;89:298302.

4 Johnson CD, Abu-Hilal M: Persistent organ failure during the first week as a marker of fatal outcome in acute pancreatitis. Gut 2004;53:1340-1344.

5 Muckart DJ, Bhagwanjee S: American College of Chest Physicians/Society of Critical Care Medicine Consensus Conference definitions of the systemic inflammatory response syndrome and allied disorders in relation to critically injured patients. Crit Care Med 1997; 25:1789-1795.

6 Banks PA, Freeman ML; Practice Parameters Committee of the American College of Gastroenterology: Practice guidelines in acute pancreatitis. Am J Gastroenterol 2006;101:2379-2400

7 Kivilaakso E, Fraki O, Nikki P, Lempinen M: Resection of the pancreas for acute fulminant pancreatitis. Surg Gynecol Obstet 1981;152:493-498.

8 Hollender LF, Meyer C, Marrie A, Costa JS, Castellanos JG: Role of surgery in the management of acute pancreatitis. World J Surg 1981;5:361-368.

$\checkmark 9$ Alexandre JH, Guerrieri MT: Role of total pancreatectomy in the treatment of necrotizing pancreatitis. World J Surg 1981;5:369-377.

10 Autio V, Juusela E, Lauslahti K, Markkula H, Pessi T: Resection of the pancreas for acute hemorrhagic and necrotizing pancreatitis. World J Surg 1979;3:631-639.

11 Beger HG, Krautzberger W, Bittner R, Block S, Büchler M: Results of surgical treatment of necrotizing pancreatitis. World J Surg 1985;9:972-979.

12 Beger HG, Büchler M, Bittner R, Block S, Nevalainen $\mathrm{T}$, Roscher R: Necrosectomy and postoperative local lavage in necrotizing pancreatitis. Br J Surg 1988;75: 207-212.

13 Bradley EL 3rd, Allen K: A prospective longitudinal study of observation versus surgical intervention in the management of necrotizing pancreatitis. Am J Surg 1991;161:19-24.

14 Rau B, Pralle U, Uhl W, Schoenberg MH, Beger HG: Management of sterile necrosis in instances of severe acute pancreatitis. J Am Coll Surg 1995;181:279-288.

15 Runzi M, Niebel W, Goebell H, Gerken G, Layer P: Severe acute pancreatitis: nonsurgical treatment of infected necroses. Pancreas 2005;30:195-199.
16 Mouli VP, Sreenivas V, Garg PK: Efficacy of conservative treatment, without necrosectomy, for infected pancreatic necrosis: a systematic review and metaanalysis. Gastroenterology 2013;144:333-340.e332.

17 van Santvoort HC, Bakker OJ, Bollen TL, et al.; Dutch Pancreatitis Study Group: A conservative and minimally invasive approach to necrotizing pancreatitis improves outcome. Gastroenterology 2011;141:12541263.

18 Gerzof SG, Banks PA, Robbins AH, Johnson WC, Spechler SJ, Wetzner SM, Snider JM, Langevin RE, Jay ME: Early diagnosis of pancreatic infection by computed tomography-guided aspiration. Gastroenterology 1987;93:1315-1320.

19 Working Group IAP/APA Acute Pancreatitis Guidelines: IAP/APA evidence-based guidelines for the management of acute pancreatitis. Pancreatology 2013; 13:e1-15.

20 Freeny PC, Hauptmann E, Althaus SJ, Traverso LW, Sinanan M: Percutaneous CT-guided catheter drainage of infected acute necrotizing pancreatitis: techniques and results. AJR Am J Roentgenol 1998;170:969-975.

21 Papachristou GI, Takahashi N, Chahal P, Sarr MG, Baron TH: Peroral endoscopic drainage/debridement of walled-off pancreatic necrosis. Ann Surg 2007;245: 943-951.

22 van Santvoort HC, Besselink MG, Bollen TL, Buskens E, van RB, Gooszen HG: Case-matched comparison of the retroperitoneal approach with laparotomy for necrotizing pancreatitis. World J Surg 2007;31:16351642.

23 Horvath KD, Kao LS, Ali A, Wherry KL, Pellegrini CA, Sinanan MN: Laparoscopic assisted percutaneous drainage of infected pancreatic necrosis. Surg Endosc 2001;15:677-682.

24 Freeman ML, Werner J, van Santvoort HC, Baron TH, Besselink MG, Windsor JA, Horvath KD, vanSonnenberg E, Bollen TL, Vege SS; International Multidisciplinary Panel of Speakers and Moderators: Interventions for necrotizing pancreatitis: summary of a multidisciplinary consensus conference. Pancreas 2012;41: 1176-1194.

25 Bradley EL 3rd, Dexter ND: Management of severe acute pancreatitis: a surgical odyssey. Ann Surg 2010; 251:6-17.

26 Mier J, Leon EL, Castillo A, Robledo F, Blanco R: Early versus late necrosectomy in severe necrotizing pancreatitis. Am J Surg 1997;173:71-75.

27 Besselink MG, Verwer TJ, Schoenmaeckers EJ, Buskens E, Ridwan BU, Visser MR, Nieuwenhuijs VB, Gooszen HG: Timing of surgical intervention in necrotizing pancreatitis. Arch Surg 2007;142:1194-1201.
28 Uhl W, Warshaw A, Imrie C, Bassi C, McKay CJ, Lankisch PG, Carter R, Di ME, Banks PA, Whitcomb DC, Dervenis C, Ulrich CD, Satake K, Ghaneh P, Hartwig W, Werner J, McEntee G, Neoptolemos JP, Büchler MW: IAP Guidelines for the surgical management of acute pancreatitis. Pancreatology 2002;2:565573

29 Hungness ES, Robb BW, Seeskin C, Hasselgren PO, Luchette FA: Early debridement for necrotizing pancreatitis: is it worthwhile? J Am Coll Surg 2002;194: 740-744.

30 Fernandez-del Castillo C, Rattner DW, Makary MA, Mostafavi A, McGrath D, Warshaw AL: Debridement and closed packing for the treatment of necrotizing pancreatitis. Ann Surg 1998;228:676-684.

31 Rattner DW, Legermate DA, Lee MJ, Mueller PR, Warshaw AL: Early surgical debridement of symptomatic pancreatic necrosis is beneficial irrespective of infection. Am J Surg 1992;163:105-109.

32 Werner J, Feuerbach S, Uhl W, Büchler MW: Management of acute pancreatitis: from surgery to interventional intensive care. Gut 2005;54:426-436.

33 Yokoe M, Takada T, Mayumi T, et al: Japanese guidelines for the management of acute pancreatitis: Japanese Guidelines 2015. J Hepatobiliary Pancreat Sci 2015;22:405-432.

34 van Baal MC, van Santvoort HC, Bollen TL, Bakker OJ, Besselink MG, Gooszen HG; Dutch Pancreatitis Study Group: Systematic review of percutaneous catheter drainage as primary treatment for necrotizing pancreatitis. Br J Surg 2011;98:18-27.

35 Greenberg JA, Hsu J, Bawazeer M, Marshall J, Friedrich JO, Nathens A, Coburn N, May GR, Pearsall E, McLeod RS: Clinical practice guideline: management of acute pancreatitis. Can J Surg 2016;59:128-140.

36 Nadkarni N, D’Cruz S, Kaur R, Sachdev A: Successful outcome with conservative management of emphysematous pancreatitis. Indian J Gastroenterol 2013;32: 242-245.

37 Pascual I, Sabater L, Anon R, Calvete J, Pacheco G, Munoz E, Lizarraga J, Sastre J, Pena A, Mora F, PerezGriera J, Ortega J, Benages A: Surgical versus nonsurgical treatment of infected pancreatic necrosis: more arguments to change the paradigm. J Gastrointest Surg 2013;17:1627-1633.

38 Al-Sarireh B, Mowbray NG, Al-Sarira A, Griffith D, Brown TH, Wells T: Can infected pancreatic necrosis really be managed conservatively? Eur J Gastroenterol Hepatol 2018;30:1327-1331.

39 Alsfasser G, Schwandner F, Pertschy A, Hauenstein K, Foitzik T, Klar E: Treatment of necrotizing pancreatitis: redefining the role of surgery. World J Surg 2012; 36:1142-1147. 